\title{
REFLECTIONS ON THE ISLAMIC LITERATURE OF THE GOLDEN HORDE: ON THE OCCASION OF THE PUBLICATION OF THE QALANDAR-NĀME
}

\author{
Uli Schamiloglu ${ }^{1,2}$ \\ ${ }^{1}$ Nazarbayev University \\ Nur-Sultan, Republic of Kazakhstan \\ uli.schamiloglu@nu.edu.kz \\ ${ }^{2}$ University of Wisconsin-Madison \\ Madison, USA \\ uschamil@wisc.edu
}

\begin{abstract}
This article was presented at a roundtable devoted to a discussion of the Qalandar-nāme. The author, basing himself on the 9 chapters of the monumental Qalandarnāme published to date with commentary, tries to compare this work with what else is known about Islamic civilization in the Golden Horde in this period. In particular, he examines the account of Ibn Batțūta and compares the Persian-language Qalandar-nāme with the Turkic works on the history of the prophets (Q1sas ül-änbiya), a Sufi manual ( $\mathrm{Mu}^{\mathrm{c}}$ in ülmürid), two romantic poems (Qutb's Xusrev u Şirin and Khorezmi's Muhabbätname), and a handbook of Islam (Nähc ül-färadis). The author finds similarities between the works of Sufi literature and the Qalandar-nāme. He concludes by posing a series of questions for future researchers, including whether this work can also be seen as a response to the Black Death, similar to the Nähc ül-färadis, as the author has argued elsewhere.
\end{abstract}

Keywords: Golden Horde, Qalandar-nāme, Nähc ül-färadis, Black Death

For citation: Schamiloglu U. Reflections on the Islamic Literature of the Golden Horde: On the Occasion of the Publication of the Qalandar-nāme. Zolotoordynskoe obozrenie $=$ Golden Horde Review. 2021, vol. 9, no. 2, pp. 264-271. DOI: 10.22378/23136197.2021-9-2.264-271

I am honored to share my brief reflections on the Nehc ül-feradis and other Islamic literary works written in the Golden Horde as well as sources about Islam in the Golden Horde on the occasion of the conference celebrating the publication of the Russian translation of the Qalandar-nāme and the opening of the Islamic Academy in Bolgar (September 3-5, 2017) ${ }^{1}$. Since I had not had an opportunity to study this work previously, except for the first 9 chapters which have been published separately in Russian translation, a more detailed study of the Qalandarnāme itself is most certainly a desideratum for the future.

According to the translators, editors, and commentators contributing to the Golden Horde Review, the Qalandar-nāme was a Persian-language work devoted to Islamic theology with a Sufi orientation written in Persian by Abū Bakr

${ }^{1}$ Originally presented as: "Nehc ül-feradis: Altın Urdadagı Islam turında beleşmä kitabı”, Roundtable on the Kalandarname/Conference on the Spiritual Silk Way. On the Occasion of the Opening of the Islamic Academy in Bolgar (Kazan/Bolgar, September 3-5, 2017). 
Qalandar Rūmī, a native of Aksaray in Anatolia. This wide-ranging work was written in the Golden Horde in the mid-fourteenth century C.E. during the time of the khans Muhammad Özbek and Canıbek. Abu Bakr Qalandar Rumi himself was a "Sufi, great scholar, [and] imam of a mosque in the city of Staryy Krym" [1, p. 251-252]. The first 9 chapters of this 800 page manuscript were published 2014-2016:

Chapter 1, "The Unity of God (Tavhīd)" [1]

Chapter 2, "Praise and Blessing upon Muhammad Muștafā" [2]

Chapter 3, "In Praise of Abū Bakr, Commander of the Faithful" [3]

Chapter 4, "In Praise of "Umar, Commander of the Faithful" [4]

Chapter 5, "In Praise of "Usmān, Commander of the Faithful" [5]

Chapter 6, "In Praise of "Alī, Commander of the Faithful" [6]

Chapter 7, "In Praise of Hasan and Husayn, Commanders of the Faithful" [6]

Chapter 8, "In Praise of the Four Imāms" [7]

Chapter 9, "The Night Ascension $\left(M i^{c} r \bar{a} c\right)$ of the Prophet (Peace be upon him!)" [8]

The rediscovery and publication of this work by Ilnur Mirgaleev, Head of the Usmanov Center for Research on the Golden Horde and Tatar Khanates of the Marjani Institute of History of Tatarstan Academy of Sciences, is certainly one of the greatest contributions to the study of Islam in the Golden Horde in the last 100 years or more. While it has been my rare privilege to obtain a copy of the facsimile of this work published earlier, I have not had the time to study it or the translation carefully yet $[9 ; 10]$. It appears that the serial publication of the translation with commentary is only at the beginning of a very long road to publication. Commenting on this work will no doubt occupy scholars for many years and decades to come. Nevertheless, we already have enough of a sense of what this work might be about to be able to contextualize it as a fundamental - though hitherto unknown to scholarship - product of the Islamic civilization of the Golden Horde. In the rest of my presentation I will try to contextualize this work within the range of other sources for the study of Islam in the Golden Horde.

So much of what we know about Islam in the Golden Horde is thanks to the detailed unique information offered by the great traveler Ibn Battūta. During his travels through the territory of the Golden Horde circa January 1333, Ibn Batțuta found mosques, religious judges, and Sufi hospices (zāwiya) to be ubiquitous. In the town of Q1rım, where he stayed in a hospice led by the sheykh Zāda al-Xurāsān̄, there was a chief religious judge $(q \bar{a} d \vec{\imath})$ of the Hanafî legal school as well as religious judge of

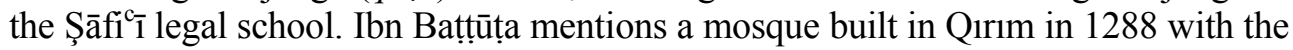
aid of the Egyptian ruler Baybars, but we also know of two other mosques, including the congregational mosque of Q1rım that Özbek had built in he found 1314 [16, ii, p. 470-473 and 472 n.]. In Kaffa he found a mosque and in Azaq (Azov) found a religious judge and students, and he also witnessed recitations of the Qur'ān followed by a sermon and blessings. There were also other kinds of religious singing in Arabic which were then translated into Persian as well as into Turkic.

In the great traveler's description Saray Berke was an exceptional city for its religious life as well. Saray had 13 mosques for Friday congregational prayers, including one for the Şāfi ${ }^{c} \overline{1}$ school, and there were many more smaller mosques. He 
met religious scholars there from around the central Islamic lands. In Xwarezm the great traveler found a great center of Islamic religion and learning which neither Saray Batu nor the more recently-established city of Saray Berke could possibly rival. (Time does not permit me to review this here, but this is a region whose history is more closely tied to the history of Islam in sedentary Central Asia.)

Ibn Battututa is a unique source for some many important topics. His account allows us to conclude that in Xwarezm and in Bulğar (the latter probably not visited by Ibn Batțūta), Islamic devotion continued - we might say from the perspective of the 1330s without serious disruption - from pre-Mongol times, though the Mongol conquests helped create important martyrs, especially among the leaders of Sufi orders in Xwarezm and elsewhere in Central Asia such as Nacm ad-Dīn al-Kubrā. It is difficult to say how old the Islamic infrastructure in the centers visited by the great traveler in the North Caucasus foreland and the Crimea might have been, but it can certainly predate the arrival of the Mongols by centuries as well.

The rapid development of orthodox Islamic institutions in Saray within the space of decades or possibly even just years was spectacular. Equally spectacular by the time of Ibn Battututa's visit was the full participation in religious life by the highest levels of the ruling elite, including Özbek Xan's humiliation before an ascetic religious leader. Every Friday, the Muslim day of rest, Özbek Xan would visit the hospice of the learned congregational preacher (imām) $\mathrm{Nu}^{\mathrm{c}} \mathrm{ma} n$ ad-Dīn alXwārizmī, "one of the eminent shaikhs and a man of fine character, generous in soul, of exceeding humility but also of exceeding severity towards the possessors of this world's goods". Although this sheykh would humble himself before poor brethren, the needy, and travelers, his conduct towards Özbek was the opposite.

The information provided us by Ibn Battututa allows us to understand the role of the Sufi orders in promoting Islam among broader segments of the population throughout the religious frontier areas of the Golden Horde. As in the conversions of Berke and Özbek to Islam, the Sufi leaders must have participated in missionary activity among broader segments of society as they did in other periods. Perhaps it is already possible to speak of a missionary Islam propagated by Sufi orders in the territories of the Golden Horde in the time of Berke Xan. There can be no question that there was such a missionary Islam by the time of Özbek Xan, since the hospices described by Ibn Battututa were by their very nature intended to serve as nodes in an Islamic religious and missionary network throughout the territory of the patrimony of Batu.

We can now turn to the best-known Islamic Turkic texts which allow us to speak about Sufism in the world of the Golden Horde. The most prominent of these is Rabğuzi's Qısas ül-änbiya' ("Tales of the Prophets") [20; 21; 13, p. 276-279]. This important work, which later became one of the most popular works among the Muslim Turks of the Russian Empire in the nineteenth and early twentieth centuries, is a collection of stories about the Creation and the prophets from Adam through Muhammad and other early Islamic figures. It was composed around 1310 in Ribat-i Oğuz in Türkistan for a devout local Chinggisid, Nasirüddin Toqbuğa, who would cry while hearing verses from the recited [21, p. 7]. By the nineteenth century this work would be an important source of information on Islam for Tatars of the Volga-Ural region, who were taught by religious teachers who were influenced by the traditions of mystical Islam. 
Another work, the $M u^{c}$ in $\ddot{u} l$-mürid, was a short religious work composed in Ürgenç in 1313 [23;24;25;11;13, p. 279-280]. The contents of this work reveal it to have been intended for aspirants in a Sufi order because of its heavy emphasis on the attainment of mystical knowledge ( $m \ddot{a}$ r rifät) of God, the declaration of one's intention to become a mystic (iradät), otherwise without giving up his identity he cannot become a disciple (murid) of a Sufi shaykh, whom he must imitate (iqtida) and thereby become part of a community (suhba). The comparison is made to an arrow: Truth (haqiqat) is the tip of the arrow (arrowhead), the Sufi Order (tariqat) is the shaft of the arrow, and Religious Law (şäric ät) is the feathers at the end of the arrow (fletching). Making progress on the path (süluk) the novice will learn to give thanks (şükr) to God and to remember (zikr) the Holy Men (äränlär).

Other works from a bit later in the fourteenth century include the romantic poems Xusrev $u$ Şirin, which is adapted by Qutb from the Persian poem of the same name by Nizāmī [15; 27; and the discussion in 13, p. 280-285] and Xorezmi's romantic poem Mähabbätname (also: Muhabbätname) [14; 17; 22; and the discussion in 13, p. 285-287]. In addition to these two poems there is also the religious treatise Nehc ül-feradis (discussed below). All three of these later works diverge from the strong devotional character of the Qlsas ül-enbiya' and the $M u^{c}$ in $\ddot{u} l$ murid. In contrast, the Persian-language Qalandar-nāme is situated solidly within the tradition of works exploring Islamic mystical knowledge.

A very different kind of pious religious work, not situated in the mystical tradition, is represented by the Nähc ül-färadis, which was intended as a pious work $[18 ; 19 ; 20$; and the discussion in 13, p. 287-291]. Already in the nineteenth century Şihabeddin Märcani described a manuscript of the Nähc ül-färadis (now lost) copied in Saray in 749/1358. That manuscript attributed the work to one Mahmud born in Bulğar, who found refuge in Saray, and whose family name (nisba), Kerderī, linked him with the city of Kerder in Xwarezm. Another manuscript says that the author died three days after March 25, 1360. The manuscript edited by Eckmann et al. was completed on 6 Cumādā I, 761/March 25, 1360, indicates the various sources on which it was drawn, and finally refers to the author as Muhammad b. Muhammad b. Xusräv el-Xorezmi. [12, p. 95; 18, p. 309; 19, p. 8].

This work is divided into four parts of ten chapters each. Part I, "The Positive Characteristics of the Prophet Muhammad", is a detailed account of his life, the revelation of Islam, the Hicra from Mecca to Medina, the miracles surrounding his life, his return to Mecca, the Prophet's ascent to heaven in a dream, an explanation of heaven, the battle of Huneyn, and his death. Part II, "The Positive Characteristics of the Orthodox Caliphs, the Prophet's Family, and the Four Imāms", includes accounts of the first four caliphs (Abū Bakr, 'Umar, 'Utmān, ${ }^{c} A 1 \overline{1}$ ), the Prophet's wife Fātima, the two sons Hasan and Husayn of ${ }^{c} \mathrm{Al} \overline{1}$ (who are seen as martyrs by the Shi ites), and the imāms who founded of the four major legal schools (the greatest imām Abū Ḥan̄ia, imām Şāfíc̄i, imām Mālik, imām Aḥmad Hanbal). Part III, "An Explanation of the Virtuous Deeds Bringing One Close to God" explains the virtues of praying five times a day, giving alms, fasting during Ramaḍān, making the pilgrimage to Mecca, treating parents with respect, eating religiously-pure ( halāl) food, proper etiquette (including distinguishing good from evil), devotion at night, and patience and contentment. Part IV, "An Explanation of the Evil Deeds Distancing One From God", explains the evils of spilling blood unjustly, fornication, drinking alcoholic beverages, haughtiness, lying, loving this world, hypocrisy 
and dissimulation (riy $\bar{a}$ ve $\operatorname{sem}^{c} a$ ), malice and envy, hubrus and neglect, and the hope of a long life.

As I have argued elsewhere, the contents of this work reveal it to have been a work of an orthodox Sunnī character simply describing the basic knowledge and precepts that one needs to be a good Muslim. It includes balanced information on all the Muslim legal schools, reflecting the composition of Sunnī legal scholars in the cities of the Golden Horde as described by Ibn Battūța. If I we compare it with handbooks for Sufi orders in this period, this work was not designed for a murid, an aspirant in a Sufi order, as discussed above [26].

The existence of both traditions begs the question of whether there might have been any tensions between these two separate views of religion. After all, orthodox Islam was apparently dominant in the cities of the Golden Horde along the Volga, while in Xwarezm and elsewhere in the south there was a strong Sufi tradition that had even served a prominent role in the conversion of Berke Xan to Islam. We cannot know whether the Nähc ül-färadis was intended to serve as an educational purpose or if it was simply a pious act on the part of the author.

In this regard, there is one further observation that I would offer in this regard, namely that there was an increase in a desire to learn about how to get to heaven, if we may recall the subtitle to this work. This could be a function of the fact that the number of converts to Islam was increasing. As I have argued elsewhere, however, this was also the period of the ravages of the Black Death through the territories of the Golden Horde. As in Western Europe, the Black Death must have had a profound impact on society in these territories as well. In Western Europe, one of the responses was an increased religiosity, a greater concern with death and the punishments brought down by God in art and literature. There is no doubt in my mind that the population of the Golden Horde had many reasons to be concerned about whether it got to heaven or not, and that this work was connected with that fear. I see the creation of this work in the Islamic Turkic literary language of the Golden Horde as a pious act in order to be a better, more pious Muslim by reproducing a work to teach others about the basic principles of Islam. This should be understood as a response to the punishment unleashed by God in the form of the Black Death (and possibly other diseases) in the mid-fourteenth century.

Finally let us return to the topic of our roundtable, namely Abū Bakr Qalandar Rūmī's Qalandar-nāme, which was also written in the mid-fourteenth century during the reigns of Özbek Khan and Canıbek Khan. To conclude, based upon just a passing familiarity with this work from 9 chapters published so far in the Golden Horde Review, I would raise a number of questions about this work:

1. To what extent did the Qalandar-näme (in Persian) draw upon the same sources as the Nähc ül-färadis (in Turkic)?

2. Could the Qalandar-näme have served as a source for the Nehc ül-feradis? In my superficial understanding of the Qalandar-nāme, it is a much more detailed text including many elements of Sufism.

3. If there is any relationship between these two texts, did the Nähc ül-färadis strip its content down to the basics of Orthodox Islam? (Whether there is any relationship or not, it is worth comparing the Qalandar-nāme with the Nähc ül-färadis to bring the religious and ideological orientation of the Qalandar-näme into sharper focus). 
4. I have argued elsewhere that the composition of the Nähc ül-färadis as a response to plague and the different possible dates for the death of the author/copyist coincides perfectly with what we know about the chronology of the waves of Black Death visiting the Middle Volga region and the end of the Volga Bulgarian language (a Western Turkic epigraphical language used for funerary inscriptions). Since the Qalandar-nāme is written in the same period (but beginning in the reign of Özbek Khan, presumably closer to the time of his death in 1343 than the beginning of his reign in 1313), is there evidence to suggest that the Qalandar-näme was also an example of increased religiosity in this period, in other words also a response to the Black Death of the fourteenth century? If the work was written in the Crimea, there is sufficient evidence for waves of plague in the Crimea, too. I suspect that the answers to these and other questions will occupy us for a long time yet...

\section{REFERENCES}

1. Abu Bakr Qalandar. Qalandar-name. Chapter 1. "Monotheism”. Ismagilova M.R. (tr.), Shagaviev D.A. (ed.). Golden Horde Review, 2014, no. 2, pp. 243-252. (In Russian)

2. Abu Bakr Qalandar. Qalandar-name. Chapter 2. "Praise and blessing upon Muhammad Mustafa". Ismagilova M.R. (tr.), Shagaviev D.A. (ed.). Golden Horde Review, 2014, no. 3, pp. 207-214. (In Russian)

3. Abu Bakr Qalandar. Qalandar-name. Chapter 3. "Praises to Abu Bakr, Commander of the Faithful". Ismagilova M.R. (tr.), Shagaviev D.A. (ed.). Golden Horde Review, 2014, no. 4, pp. 198-207. (In Russian)

4. Abu Bakr Qalandar. Qalandar-name. Chapter 4. "Praising 'Umar, Commander of the Faithful”. Ismagilova M.R. (tr.), Shagaviev D.A. (ed.). Golden Horde Review, 2015, no. 1, pp. 171-177. (In Russian)

5. Abu Bakr Qalandar. Qalandar-name. Chapter 5. "The praise of 'Uthman, Commander of the Faithful”. Ismagilova M.R. (tr.), Shagaviev D.A. (ed.). Golden Horde Review, 2015, no. 2, pp. 187-196. (In Russian)

6. Abu Bakr Qalandar. Qalandar-name. Chapter 6. "Praising 'Ali, Commander of the Faithful". Chapter 7. "Praising Hasan and Hussein, Commanders of the Faithful". Shamsimukhametova M.R. (tr.), Shagaviev D.A. (ed.). Golden Horde Review, 2016, no. 1, pp. 193-207. (In Russian)

7. Abu Bakr Qalandar. Qalandar-name. Chapter 8. "Praises to Four Imams". Shamsimukhametova M.R. (tr.), Shagaviev D.A. (ed.). Golden Horde Review. 2016, vol. 4, no. 2, pp. 443-449. (In Russian)

8. Abu Bakr Qalandar. Qalandar-name. Chapter 9. “The Ascension (Mi'raj) of the Messenger [of Allah] (Peace Be upon Him!)". Gibadullin I.R. (tr. and ed.), Shamsimukhametova M.R. (tr.). Golden Horde Review. 2016, vol. 4, no. 4, pp. 861-867. DOI: 10.22378/2313-6197.2016-4-4.861-867. (In Russian)

9. Abu Bakr Qalandar Rumi. Qalandar-name. Facsimile. Mirgaleev I.M. (ed.). Kazan: Marjani Institute of History of Tatarstan Academy of Sciences, 2015. 800 p. (In Persian)

10. Abu Bakr Qalandar Rumi. Kalandar-name: izbrannoe [Qalandar-name: Selected Parts]. Gibadullin I.R. (tr. and ed.), Shamsimukhametova M.R. (tr.). Kazan: Marjani Institute of History of Tatarstan Academy of Sciences, 2017. 1044 p. (In Russian)

11. Bodrogligeti A.J.E. The authorship and sources of the Muinu'l-murid. Tractata Altaica: Denis Sinor, Sexagenario Optime de Rebus Altaicis Merito Dedicata. Heissig W. et al. (eds). Wiesbaden: Harrassowitz, 1976, pp. 87-105. 
12. Bombaci A. Histoire de la littérature turque. Mélikoff I. (tr.). Paris, 1968. 437 p. (In French)

13. Eckmann J. Die kiptschakische Literatur, I: Die Literatur von Chwarezm und der Goldenen Horde. Philologiae Turcicae Fundamenta. Boratov P.N. (ed.). Wiesbaden, 1964, vol. II, pp. 275-296. (In German)

14. Gandjeï T. Il 'Muhabbatnāma' di Horazmī. Annali dell'Instituto Universitario Orientale de Napoli. N.S. 1957, no. 6, pp. 131-161; 1958, no. 7, pp. 135-166. (In Italian)

15. Hacıeminoğlu M.N. Kutb’un Husrev ü Şirin'i ve dil hususiyetleri. Istanbul, 1968. 477 p. (In Turkish)

16. Ibn Batțūta. The Travels of Ibn Battututa, A.D. 1325-1354. Gibb H.A.R (tr.). Cambridge, 1958-1971. xvii $+269 \mathrm{p}$.

17. Nadjip E.N. Khorezmi. Mukhabbat-name. Moscow, 1961. $224+48$ p. (In Russian)

18. Nehcü'l-ferādīs. Uştmahlarnıng açuq yolı (Cennetlerin açık yolu). Eckmann J. et al. (eds). Ankara: Atatürk Kültür, Dil ve Tarih Yüksek Kurumu, 1995. 2 Vols. (In Turkish)

19. Mäxmüd äl-Bolgari. Nähcel-färadis. Nurieva F. (ed.). Kazan, 2002. (In Tatar)

20. Rabğuzi Nosiruddin Burhonuddin. Kıșașü'l-Enbiyā (Peygamber Kıssalarl). Ata A. (ed.). Ankara, 1997-1998. 3 Vols. (In Turkish)

21. Rabğuzi Nosiruddin Burhonuddin. The Stories of the Prophets. Qisas al-anbiyā', An Eastern Turkish Version. Boeschoten H.E. et al. (eds and tr.). Leiden: Brill, 1995. 787 p. (In Turkish)

22. Shcherbak A.M. Oguz-name. Mukhabbat-name. Pamyatniki drevneuygurskoy $i$ starouzbekskoy pis'mennosti [Written Sourses of Ancient Uigur and Old Uzbek Writing]. Moscow: Oriental literature, 1959. 172 p. (In Russian)

23. Togan Z.V. Harezm'de Yazılmış Eski Türkçe Eserler. Türkiyat Mecmuası. 1928, vol. 2, pp. 315-345. (In Turkish)

24. Toparlı R. Mu'înü'l-Mürîd. Erzurum, 1988. lxxii + 287 p. (In Turkish)

25. Mu'inü'l-Mürid. Toparlı R. and Argunşah M. (eds). Ankara, 2015. 332 p. (In Turkish)

26. Waley M.I. A Kubrawī manual of Sufism: The Fușūṣ al-ādāb of Yahyā Bākharzī. The Legacy of Mediaeval Persian Sufism. Lewisohn L. (ed.). New York, 1992, pp. 289310.

27. Zajaczkowski A. Najstarsza wersja turecka Husräv u Šìin Quṭba. Warsaw, 1958, vol. 1. 304 p. (In Polish)

About the author: Uli Schamiloglu - Ph.D. (History), Professor, Nazarbayev University (53, Kabanbay Batyr Ave, Nur-Sultan 010000, Republic of Kazakhstan); Professor Emeritus, University of Wisconsin-Madison (1220 Linden Drive, Madison, WI 53706, USA). E-mail: uli.schamiloglu@nu.edu.kz, uschamil@wisc.edu 


\title{
РАЗМЫШЛЕНИЯ ОБ ИСЛАМСКОЙ ЛИТЕРАТУРЕ ЗОЛОТОЙ ОРДЫ: ПО СЛУЧАЮ ПУБЛИКАЦИИ КАЛАНДАР-НАМЕ
}

\author{
Юлай Шамильоглу ${ }^{1,2}$ \\ ${ }^{1}$ Назарбаев Университет \\ Нур-Султан, Республика Казахстан \\ uli.schamiloglu@nu.edu.kz \\ ${ }^{2}$ Висконсинский университет в Мадисоне \\ Мадиссон, США \\ uschamil@wisc.edu
}

Цель исследования: эта статья была прочитана на круглом столе, посвященном обсуждению Каландар-наме. Автор, основываясь на 9 главах монументальной Каландар-наме, опубликованных на сегодняшний день с комментариями, пытается сравнить это произведение с тем, что еще известно об исламской цивилизации в Золотой Орде в этот период.

Материалы исследования: в частности, он рассматривает рассказ Ибн Баттуты и сравнивает Каландар-наме на персидском языке с тюркскими литературными произведениями по истории пророков (Кысас ул-анбия), суфийским справочником (Муин ул-мурид), двумя романтическими стихотворениями (Хусрев у Ширин Кутба и Мухаббатнаме Хорезми), а также справочником по исламу (Нахдж ул-фарадис). Автор находит сходство между произведениями суфийской литературы и Каландар-наме.

Результаты исследования и научная новизна: в заключение автор задает ряд вопросов будущим исследователям, в том числе: можно ли рассматривать эту работу как ответ на «Черную смерть», подобную Нахдж ул-фарадис, как он утверждал в другом месте.

Ключевые слова: Золотая Орда, Каландар-наме, Нахдж ал-Фарадис, Черная смерть

Для цитирования: Schamiloglu U. Reflections on the Islamic Literature of the Golden Horde: On the Occasion of the Publication of the Qalandar-nāme // Золотоордынское обозрение. 2021. Т. 9, № 2. C. 264-271. DOI: 10.22378/2313-6197.2021-92.264-271

Сведения об авторе: Юлай Шамильоглу - Ph.D. (история), профессор, Назарбаев Университет (010000, пр. Кабанбай батыра, 53, Нур-Султан, Республика Казахстан); профессор, Висконсинский университет в Мадисоне (1220 Linden Drive Drive, Madison, WI 53706, USA). E-mail: uli.schamiloglu@nu.edu.kz, uschamil@wisc.edu 